\title{
Social and Economic Imperatives for the Production of Wedding Poetry in the Dutch Republic A Data-Driven Analysis
}

\author{
Nina Geerdink \\ Utrecht University, the Netherlands \\ n.geerdink@uu.nl \\ Alie Lassche \\ Leiden University, the Netherlands \\ a.w.lassche@hum.leidenuniv.nl
}

\begin{abstract}
In this article, we show the importance of both social and economic imperatives for authors and printers active in the genre of wedding poetry, and the interaction between these imperatives. The lack of systematic evidence and the fragmented nature of previous research has led to the dominance of tentative interpretations in studies of wedding poetry. Necessary, therefore, is a broader and more inclusive approach of the genre as a whole. We have thus combined a literature review with a quantitative analysis, exploring metadata of over 3,500 publications of wedding poetry (year of publication, names of brides, grooms, printers and authors) in the Dutch Republic between 16oo-176o.
\end{abstract}

\section{Keywords}

wedding poetry - Dutch Republic - network analysis - data analysis - social imperatives - economic imperatives 


\section{Introduction $^{1}$}

In a 1733 issue of the Dutch journal De Hollandsche Spectator, an unknown poet complains about the obligation he feels, at his marriageable age, to write wedding poetry for all his friends. ${ }^{2}$ The genre of wedding poetry, originating in the classical tradition and appropriated by humanists and Renaissance poets during the fifteenth and sixteenth centuries, had gained ground in the vernacular during the seventeenth century. ${ }^{3}$ In the Dutch Republic, poets like Pieter Cornelisz. Hooft and especially Joost van den Vondel, adapting classical

1 This article is written as part of Nina Geerdink's Nwo veni project Poets and Profits. A New History of Literary Authorship in the Dutch Republic, 1550-1750. The authors would like to thank José de Kruif, Digital Humanities Lab Utrecht University, and Joris Veerbeek for their help in preparing data and Marieke van Delft from the Royal Library, The Hague, for sharing data. Anna de Haas, José de Kruif, colleagues of the Utrecht University early modern Dutch literature department, colleagues of the Golden Agents project, and anonymous reviewers read earlier versions of this article and provided us with useful comments.

2 J. van Effen, De Hollandsche Spectator. Aflevering 151-195: 7 april 1733-7 september 1733, ed. M. de Niet (Leiden 1999), pp. 49-57.

3 The departure point for this paragraph is a description of the conventions within the genre and its development over time in both a European and a Dutch context, see N. Geerdink, 'The Appropriation of the Genre of Nuptial Poetry by Katharina Lescailje (1649-1711)', in: A. Gilleir, A.C. Montoya \& S. van Dijk, Women Writing Back / Writing Women Back. Transnational Perspectives from the Late Middle Ages to the Dawn of the Modern Era (Boston/Leiden 2010[a]), pp. 163-20o, pp. 166-8. This description is pre-eminently based on Schenkeveld-van der Dussen's publications: M.A. Schenkeveld-van der Dussen, 'Christus, Hymenaeus of de "Teelzucht", in: S.F. Witstein \& E.K. Grootes, Visies op Vondel na honderd jaar. Een bundel artikelen ter gelegenheid van de driehonderdste sterfdag van Joost van den Vondel (Den Haag 1979), pp. 11-25; 'Theorie en poëzie. Een epithalamium van Six van Chandelier', in: De nieuwe taalgids, 72 (1979), pp. 391-8; 'Vondel als gelegenheidsdichter en vriend. Het bruiloftsgedicht voor Ioan van de Poll en Duifken van Gerwen', in: G. Eemeren \& F. Willaert, 't Ondersoeck leert. Studies over middeleeuwse en 17e-eeuwse literatuur ter nagedachtenis van prof. dr. L. Rens (Leuven 1986), pp. 293-300; 'Bruiloftsdichten in de tale Kanaäns. Het probleem van de onverstaanbaarheid', in: De nieuwe taalgids, 75 (1982), pp. 50-6o; 'Hochzeitsdichtung und christlicher Glaube. Einige Epithalamien Niederländischer Dichter', in: Jahrbuch für Internationale Germanistik, 8 (1980), pp. 31-7; 'Een bruiloftsdicht van Karel van Mander', in: Tijdschrift voor Nederlandse taal —en letterkunde, 92 (1976), pp. 189-202; 'Bruilofts—en liefdeslyriek in de 18e eeuw. De rol van de literaire conventies', in: De nieuwe taalgids, 67 (1974), pp. 44961. Hollantsche Parnas. Nederlandse gedichten uit de zeventiende eeuw, ed. T. van Strien (Amsterdam 1997), pp. 49-51 pays attention to literary developments in the genre, too. A late eighteenth century account of the developments in the genre can be found in Vervolg op M. Chomel, Algemeen huishoudelyk [...] konst woordenboek, Vyfde deel, zynde het XII. deel van het woordenboek (Kampen/Amsterdam 179o), pp. 3340-42, s.v. 'Huwelyksch-zang. M.A. Babin, Epithalamia. Classical Traditions and Changing Responses (Berkeley 1978), pp. 174-7 concludes that English wedding poetry in later times also increasingly diverges from classical traditions. 
conventions in an original way, established the genre in the vernacular, which soon attracted other poets, including minor poets. This resulted in a decrease in both classical aspects and originality, and a rise in Christian frameworks, conventional structures, and stylistic devices. Although the genre's literary reputation diminished, its popularity among elite circles in society at large only increased. We know that nuptial poems were performed during wedding festivities, often by the authors themselves, and were presented as a gift to the couple getting married. ${ }^{4}$ At first they were presented in manuscript, ${ }^{5}$ but by the end of the seventeenth century wealthy merchants had created a tradition of extravagant marriage parties that included printed publications with one or more epithalamia, often also dispensed as gifts to the wedding guests. ${ }^{6}$

In his complaint, the poet in De Hollandsche Spectator of 1733 addresses both the social and the economic imperatives spurring the production of wedding poetry on: he refers to poets who were paid to write wedding poems, but also suggests that anyone who was known as a poet would be expected to write such poems for friends. Although our unhappy poet would never himself write for financial advancement, he imparts that he does feel this sense of obligation. Indeed, as Luuc Kooijmans convincingly argued in his 1997 monography, friendship in the early modern period was about the exchange of favours, and social and economic favours are not easily distinguished. ${ }^{7}$ Social imperatives

4 About these practices A. Nieuweboer, 'De achttiende-eeuwse gelegenheidsdichter en zijn publiek. Van toegezongene tot toevallige lezer', in: J.J.M. Westenbroek et al., Verleidingskunst der muzen (Muiderberg 1986[a]), pp. 58-75, pp. 61, pp. 64-5; 'Welgestelden in de 18e eeuw. Huwelijk en bruiloftspoëzie', in: Ons Amsterdam, 40 (1988), pp. 338-41, p. 331; 'Haarlems literair leven in gelegenheidsgedichten (1680-1770)', in: E.K. Grootes, Haarlems Helicon. Literatuur en toneel te Haarlem vóór 1800 (Hilversum 1993), pp. 187-201, pp. 194-5; J. Bouman, Nederlandse gelegenheidsgedichten voor 1700 in de Koninklijke Bibliotheek te 's-Gravenhage. Catalogus van gedrukte gedichten op gedenkwaardige gebeurtenissen in het leven van particuliere personen (Nieuwkoop 1982), p. XV; A.G. van der Steur, Catalogus 28: Gelegenheidsgedichten. Los verschenen gedrukte gelegenheidgedichten op Nederlandse personen, $17^{e}-20 e$ eeuw (Haarlem 2004), p. 13; N. de Roever, Van vrijen en trouwen. Geschiedenis van oud-vaderlandsche zeden (Haarlem 1891), pp. 219-20.

5 Evidence for this practice can be found in random instances of such handwritten poems in family archives, for example as recorded in G.J. Honig, Catalogus der verzameling "Jacob Honig Jsz Jr" in de Zaanlandsche Oudheidkamer Eerste afdeling (Zaandijk 19oo), pp. 167-83.

6 About traditions in marriage parties among the wealthy elite see, for example, Nieuweboer, art. cit. (n. 4: 1988). Mennonites in particular maintained a tradition of extravagant wedding celebrations. See Geerdink, art. cit. (n. 3), p. 182; 'U vraagt, wij draaien? De huwelijksgedichten van Katharina Lescailje (1649-1711) voor rijke doopsgezinden', in: Gedoopt! Doopsgezinde Bijdragen nieuwe reeks, 35/36 (2010[b]), pp. 267-85, pp. 270-1, with references to studies elaborating on Mennonite wedding traditions.

7 L. Kooijmans, Vriendschap en de kunst van het overleven in de zeventiende en achttiende eeuw (Amsterdam 1997). 
can be defined as responses to requests from friends or the seizing of possibilities to obtain symbolic capital, whereas economic imperatives pre-eminently relate to financial advancement, which was enmeshed with social networks and social standing. With regard to book production, too, it is generally acknowledged that social and economic motives interacted. ${ }^{8}$

The genre of wedding poetry has received a fair amount of scholarly attention in recent decades in the wake of the cultural turn and the dominance of sociological approaches within literary studies and book history alike. ${ }^{9}$ Studying the genre's dynamics is of importance for understanding early modern Dutch publication culture in general, and writing for profit specifically. Indeed, the understudied theme of literary author's profits in the Dutch Republic is the focus of the research project of which this article is one of the results. Most research into the genre of wedding poetry, especially with regard to authors, departs from the presumption that it was pre-eminently a social phenomenon..$^{10}$ Moreover, the interaction of social and economic aspects have scarcely been studied. Whereas the genre in, for example, the most recent literary history of the seventeenth century (2008) is dealt with only as a social genre, Andrew Pettegree and Arthur der Weduwen consider it only as a commercial genre in their recently published survey of the seventeenth century book trade in the Dutch Republic (2019).11

See for example, C. Rasterhoff, Painting and Publishing as Cultural Industries. The Fabric of Creativity in the Dutch Republic, 1580-1800 (Amsterdam 2016), p. 83.

9 Compare, J. Blevins, Catullan Consciousness and the Early Modern Lyric in England (Burlington 2004); H. Dubrow, A Happier Eden. Politics of Marriage in the Stuart Epithalamium (Ithaca, N.Y. 199o). In Dutch historiography, the work of Nieuweboer and Schenkeveld-van der Dussen is pivotal. Nieuweboer focusses primarily but not only on the social context, Schenkeveld-van der Dussen primarily but not only on the literary context. See their publications art. cit. (n. 3 and 4) and A. Nieuweboer, 'Medeleven volgens voorschrift', in: Literatuur, 3 (1986[b]), pp. 15-22. About the neo-Latin epithalamia in the Dutch Republic, see H.J. van Dam, 'Taking Occasion by the Forelock. Dutch Poets and Appropriation of Occasional Poems', in: Y. Maes, J. Papy, \& W. Verbaal, Latinitas Perennis vol. II: Appropriation and Latin Literature (Leiden 2009), pp. 95-127; about the genre in the Southern Netherlands, see K. Porteman, 'Vrijen en huwen in de 17de-eeuwse Zuidelijke Nederlanden. De stem van de literatuur', in: E. van Driessche, Verliefd, Verloofd, Getrouwd (Brussel 1988), pp. 115-24.

10 Compare K. Porteman \& M.B. Smits-Veldt, Een nieuw vaderland voor de muzen. Geschiedenis van de Nederlandse literatuur 1560-1700 (Amsterdam 2008), pp. 392, 414; and most of the publications of Nieuweboer and Schenkeveld-van der Dussen, art. cit. (n. 3 and 4).

11 Porteman \& Smits-Veldt, op. cit. (n. 10); A. Pettegree \& A. der Weduwen, The Bookshop of the World. Making and Trading Books in the Dutch Golden Age (New Haven/London 2019), pp. 331-3. It is remarkable that the most recent literary history of the eighteenth 
In this article, we aim to show the importance of both social and economic imperatives for authors and printers active in the genre of wedding poetry, and to explore the interaction between these imperatives. We therefore focus on printed instead of handwritten publications of wedding poetry. ${ }^{12}$ We possess no systematic records relating to the genre, such as publishers' correspondence with either authors or commissioners, or account books providing evidence of payments from commissioning parties to authors or printers. Thanks to cataloguing initiatives undertaken in the 1980s and 199os, we do have some indication of the number of published collections with wedding poetry, as well as certain insights into the unwritten rules governing the genre and its agents. ${ }^{13}$ In-depth research, however, can primarily be found in case studies, focussing on one author or one specific context and, thus, on a relatively small number of publications containing wedding poetry. ${ }^{14}$

The lack of systematic evidence and the fragmented nature of previous research has led to the dominance of tentative interpretations in studies of wedding poetry. ${ }^{15}$ It is therefore necessary to adopt a broader and more inclusive

century does not mention the genre at all: I. Leemans \& G.J. Johannes, Worm en donder. Geschiedenis van de Nederlandse literatuur 1700-180o: de Republiek (Amsterdam 2013).

12 Although, as would be expected, handwritten wedding poems were more often written due to social imperatives, it would be interesting to include these sorts of poems for insights into the genre as a whole. The lack of catalogues or inventories with handwritten wedding poems makes this difficult, however. See note 5 . A note regarding the use of the word 'printers' and not, publisher-booksellers: we assume that within this occasional genre, with publications not intended for the book market at large, most often printers were responsible for both printing and distribution.

13 See Nieuweboer's publications, written in the context of the cataloguing initiative of the Royal Library in The Hague, art. cit. (n. 4), and also Bouman, op. cit. (n. 4); Van der Steur, op. cit. (n. 4); M. Daamen and A. Meyer, Catalogus van gedrukte Nederlandse gelegenheidsgedichten uit de zeventiende en achttiende eeuw in de Zeeuwse bibliotheek te Middelburg (Middelburg 1990).

14 This accounts for several of Schenkeveld-van der Dussen's publications, art. cit. (n. 3). See also K. Smit, Pieter Langendijk (Hilversum 20oo); and Geerdink, art. cit. (n. 3 and 6).

15 Smit, for example, in his biography of Langendijk takes it for granted that many of his wedding poems were commissioned and written because of economic imperatives: Smit, op. cit. (n. 14), pp. 138-51, pp. 193-200, pp. 250-3. Pettegree and Der Weduwen, in their profound handbook, stage the genre as part of the 'poetical service industry', which they call the most lucrative of all the poetry being written, though they do not ground this (very probable) claim in evidence. Their estimate of the number of surviving wedding pamphlets from the seventeenth century-70o-is fairly small in comparison to the thousands catalogued in Dutch collections (see below). In this vein we also find the unsubstantiated observation that weddings provided poets with 'de nodige werkgelegenheid' (proper employment) in a recent popular publication about wedding practices in the early modern period: R. van Weeren and T. de Moor, Ja, ik wil! Verliefd, verloofd, getrouwd in Amsterdam, 1580-1810 (Amsterdam 2019), p. 184. 
approach towards the genre as a whole: large-scale quantitative research. This allows us to validate, evaluate and add to the claims presented in scholarly literature about the social and economic imperatives of printed wedding poetry in the Dutch Republic.

Such an analysis is possible since (metadata of) large numbers of surviving wedding pamphlets can readily be consulted thanks to the aforementioned cataloguing initiatives from the gos. Nevertheless, we must be aware that for various reasons it is impossible to be exhaustive, or even to make grounded claims about how representative the surviving copies of wedding pamphlets might be. Publications containing wedding poems were printed for special events, presumably in small print runs, and were not esteemed highly in literary circles; it is thus easy to imagine that many publications did not survive. ${ }^{16}$ It is telling that some authors whose collected works contain a fair amount of wedding poetry are not very well represented in our dataset, in which we only included the original publications that came into being in the social context of a specific wedding. Katharina Lescailje, for example, wrote more than go wedding poems, as is evident from her posthumously published collected works, but only 38 are recorded in the catalogues we used, representing the most important catalogues containing wedding pamphlets (see below). ${ }^{17}$ Moreover, many surviving publications are probably kept in public archives and libraries that are not included in any of these catalogues, or in private archives and collections we do not know of. ${ }^{18}$ It is important to note that the catalogues we used focus mainly on wedding events in the states of Holland, specifically Haarlem and Amsterdam.

16 About lost books in general, see Pettegree \& Der Weduwen, op. cit. (n. 11), p. 16; about the assumption that especially occasional poetry got lost, see for example Nieuweboer, (n. 4: 1986[a]), who quotes a 1791 wedding poet: 'Het werk wordt (...) naa zeer korte tijd, gedoemd tot scheurpapieren' (the publication is doomed to become torn up paper very quickly).

17 See Geerdink, art. cit. (n. 3 and 6). Also in the case of Jan Jansz. Starter, for example, the number of wedding poems in his collection Friesche Lusthof (Amsterdam 1621, 12 wedding poems) surpasses the number of his publications in our dataset (3 wedding poems).

18 Compare Van der Steur, op. cit. (n. 4), p. 21. An example of a collection of wedding poems that we did not include is the Zeeland catalogue Daamen \& Meyer, op. cit. (n. 13). This catalogue contains data about 440 poems, of which 175 were written by Anthony Jansen. All but 28 of these poems are also included in our dataset. The rest of the poems in the catalogue, not included in our dataset, were written by poets with two or three poems to their names at most. We decided not to include data from this catalogue, since these publications would not influence the larger picture, whereas it would take considerable work to add the data (manually). The same goes for the collection described in Honig, op. cit. (n. 5). 
After a description of our dataset and methodology (section 1), we will successively give a general impression of the genre (section 2), then analyse social imperatives (section 3) and economic imperatives (section 4) among its participants, focussing on the interaction between these imperatives. In each section, we connect the results of a literature review with the findings of our data-driven analysis.

\section{Dataset and Methodology}

To perform our analysis, we needed data on booklets published in the genre's heyday, which according to existing literature occurred at the beginning of the eighteenth century. ${ }^{19}$ To test this claim and show developments within the genre, we decided to broaden the period from 1600 to $1760 .^{20}$ With regard to our central focus, the most important data concern the participants: who were involved, and how were they related to one another? Which authors wrote poems in booklets for which couples, printed by which printers? How many printers and authors participated incidentally in the genre, and how many were very active? Which authors and printers cooperated occasionally, and which did so frequently? Did couples with familial ties turn to the same printer or author for the production of their booklets?

To create a dataset that would enable us to answer these kinds of questions, we had to clean the available data and make some methodological decisions that should be explained here. We extracted data from three different catalogues: $(i)$ the catalogue Occasional poems until 1800 in the Netherlands (Gelegenheidsgedichten tot 1800 in Nederland, GGD), built and maintained by the Royal Library in The Hague, (ii) the Short-Title Catalogue, Netherlands (STCN) and (iii) the catalogue Occasional poems (Gelegenheidsgedichten) of Antiquariaat A.G. van der Steur, Haarlem..$^{21}$ All three consist of metadata of

19 See below, at the beginning of the section 'The Popularity of Wedding Poetry: Names and Numbers'.

20 We could have included data from booklets printed after 176o but we decided not to, because of the focus on the period $155^{0}-175^{\circ}$ of the larger research project of which this study is part. In the second half of the 18th century the dynamics of the book market, especially with regard to the relationships between printers and authors, changed, which probably influenced the balance between social and economic imperatives.

21 The first two catalogues are digitally available; we ourselves digitized the data from Van der Steur. See https://www.kb.nl/bronnen-zoekwijzers/databanken-mede-gemaakt-door -de-kb/gelegenheidsgedichten-tot-18oo-in-nederland; https://www.kb.nl/organisatie/ onderzoek-expertise/informatie-infrastructuur-diensten-voor-bibliotheken/short-title -catalogue-netherlands-stcn; and Van der Steur, op. cit. (n. 4). 
publications that contain wedding poetry. We limited our search to publications with poems written in the vernacular and published between 1600 and 176o. For each publication, we extracted the following metadata: year of publication, names of the bride and groom, name of the printer, place of printing, place of wedding, and the name(s) of the author(s). We decided to standardize the spelling of the name of individuals, as, for example, when the names of authors and printers were given variant spellings in the GGD and in the STCN catalogues. The names of different printers which, according to the STCN, referred to the same printing company were given under a single name. For example, our dataset refers to Jacob Lescailje, Jacob (erven) Lescailje, Dirk Rank, and Anthony Lescailje as 'Lescailje'. We recorded these changes in a shadow file.

It turned out to be impossible to clean the data regarding geography since the different catalogues we used did not include the same data (either place of printing or of wedding), and after separating places of printing and wedding and some sampling, these data were often unreliable. We therefore decided to omit the geographical aspect from our present analysis. We should also note here that we decided to take another uncertainty for granted: the name of the author is the name under which a poem is signed, though it is very probable that in some cases this is the name not of the author but a commissioning individual who asked a poet to write the poem on his or her behalf. ${ }^{22}$ Since these commissioners are never responsible for more than a few poems, we consider this to be a negligible bias.

The major part of our dataset comes from the catalogue GGD $(i)$, which contains data of occasional poems from several collections, including the City Archive Amsterdam (Gemeentearchief Amsterdam), Centre for Family History (Centrum voor Familiegeschiedenis [свG]), Library of the Society of Dutch Literature (Bibliotheekvan de Maatschappij der Nederlandse Letterkunde $[\mathrm{MdNL}]$ ), Museum Meermanno, and the Royal Library (Koninklijke Bibliotheek). The observed geographical bias thus most probably originates from the provenance of the sources in the GGD. The catalogue includes data pertaining to more than 6,60o publications, of which 3,382 correspond with our criteria of selection.

Another, smaller part of our dataset we collected from the STCN catalogue (ii). Since the STCN does not have a function allowing us to query all works of a genre as specific as wedding poetry, we had to manually search the catalogue by 'subject heading.. ${ }^{23}$ The result of this query was a list of 1,882 publications. Since there are also publications of wedding poetry that do not have our

22 About this practice see below, n. 57.

23 We searched with 'huwel*k', 'br*loft", and 'e*tver*niging*'. 
search terms in their titles, we were not able to include all relevant publications from STCN. However, the data of the STCN and the GGD overlap considerably. Publications from the GGD catalogue which were also included in the STCN catalogue were removed from the latter. ${ }^{24}$ Publications where the names of both author and printer were lacking were also removed, since in these cases there remains too little information to perform our analysis. We also removed the few reprints of the same publications. The final result came to 266 publications from the STCN catalogue. It is important to note that the STCN does not mention an author's name in their catalogue in cases where a publication contained more than one poem (which in most cases means that more than one author contributed to it). Thus publications in our dataset with no authors that were derived from the STCN catalogue contained in fact multiple authors.

From the catalogue of Van der Steur we collected another 48 records representing works not mentioned in the STCN and GGD catalogues. Together with the 3,382 publications from the GGD and the 266 publications from the STCN, the total amounted to 3,696 publications of Dutch wedding poetry published between 1600 and 1760, for which 633 individual printers and 3,551 individual authors were responsible. At least 8,344 poems were included in these publications. ${ }^{25}$

Each record in our dataset refers to a publication in honour of the wedding (or wedding anniversary) of one particular couple. A publication can contain one poem written by one poet, but in most cases, it is a collection of poems written by more than one poet. In some cases, one publication referred to multiple events at the same time, for example the wedding anniversary of couple $\mathrm{X}$ and the wedding of couple $\mathrm{Y}$, who were often related to each other. In such cases, we split the publication into several records, one for each wedding couple. We stalled the data in a table in which every row presented a publication. After cleaning the data, the quantitative analysis was performed using Python code. ${ }^{26}$

24 We were able to do this automatically because the duplicates in STCN have the signature 'Gel Ged' when there is a similar record in the GGD. However, since publications with both 'huwel"k' and 'br*loft"' in its title were originally included in the dataset twice, we also had to remove some duplicates manually.

25 There are 7,682 (not unique) author's names in our dataset, each responsible for a poem included in a publication. For another 662 publications, no names of authors are available. These must have had at least one poem and thus one author, which brings the minimum number of poems to 8,344 poems $(7,682+662)$.

26 The dataset and code is available at https://github.com/awlassche/netwerk -huwelijksgedichten. 


\section{The Popularity of Wedding Poetry: Names and Numbers}

People who have engaged in listing or cataloguing publications containing wedding poetry have advanced three major observations. First, from the $1650 \mathrm{os}$ onwards not only were there more publications, in absolute numbers as well as per wedding, but there was also a rise in the number of poems within these individual publications, as well as a change in appearance: the booklets were ever more lavishly decorated, for example with engravings; the paper was of better quality; the typesetting left greater room for white space; and the bindings became more exclusive. Second, the genre peaked in the first half of the eighteenth century. ${ }^{27}$ Third, specific participants-poets as well as printersrecur within the genre. It seems that some people specialized in the writing or the printing of wedding poems, and sometimes in doing both. ${ }^{28}$

We did not analyse data about material aspects of the publications (size, decorations, illustrations, typesetting, bindings), ${ }^{29}$ but our analysis confirms all aspects of the observations about the genre's quantitative development. ${ }^{30}$ As Figure 1 shows, the number of publications printed in a year between 1600 and 1670 in general did not exceed 10. Exceptions are the years 1615-1619, 16401642,1645 and 1665 , in which the number of publications per year increases to somewhere between 11 and 20, with an outlier of 32 publications in 1618. From 1670 onwards, the number of publications exponentially increased, peaking between 1720 and 1730 , with 81 publications in 1721 and 84 publications each in 1724 and 1728. From 1730 until 176o, the number of publications slightly decreases by year, although the average number of publications in this period remains 40 per year.

As Figure 2 shows, the number of publications written for one and the same occasion also increases. From 1600 onwards, we can find two or even three or four publications appearing to mark the occasion of a single wedding, but from 1690 onwards the production of two publications seems to have become

27 Nieuweboer, art. cit. (n. 4 and 9), Bouman, op. cit. (n. 4), Van der Steur, op. cit. (n. 4); Daamen \& Meyer, op cit. (n. 13).

28 See Smit, op cit. (n. 14); Geerdink, art. cit. (n. 3 and 6); Nieuweboer, art. cit (n. 4 and 9: 1986[a], 1986[b] 1993).

29 These are important for the functioning of the genre as a whole, however, since other actors such as engravers are part of the networks around it. Compare for example a recent case study about Picart's wedding prints: N. Bartelings, 'Bernard Picart's Épithalames and the teamwork of image and text', in: Jaarboek voor Nederlandse boekgeschiedenis, 26 (2019), pp. 101-119.

30 Regarding the increasing number of publications, we should note that this might be partly influenced by the general increase of numbers of surviving prints over time. 


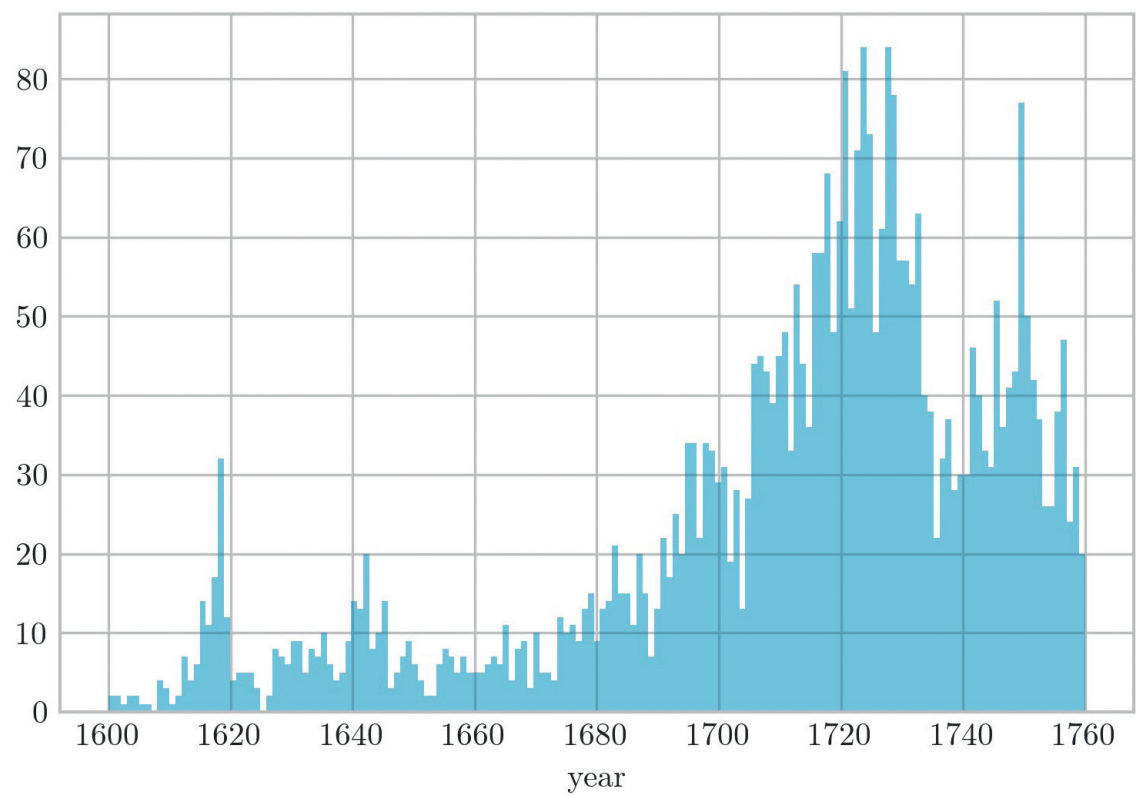

FIGURE 1 Number of publications by year

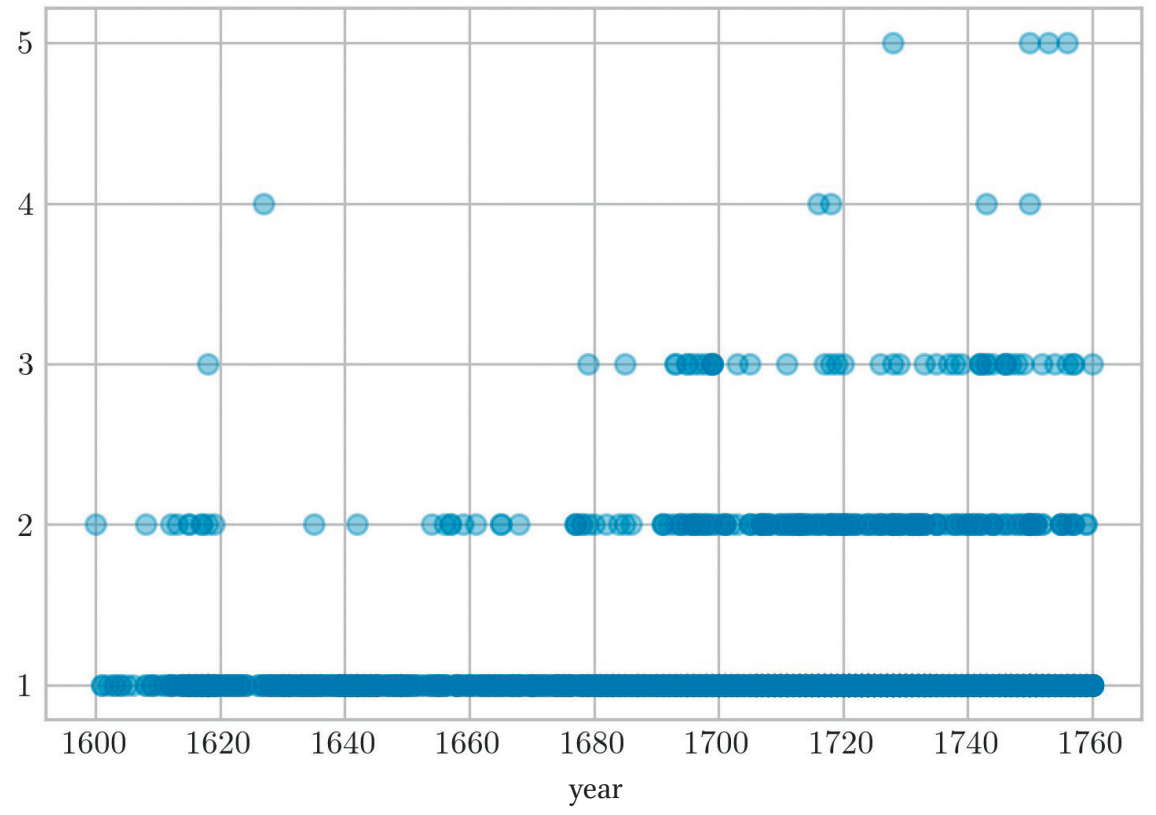

FIGURE 2 Number of publications per wedding 


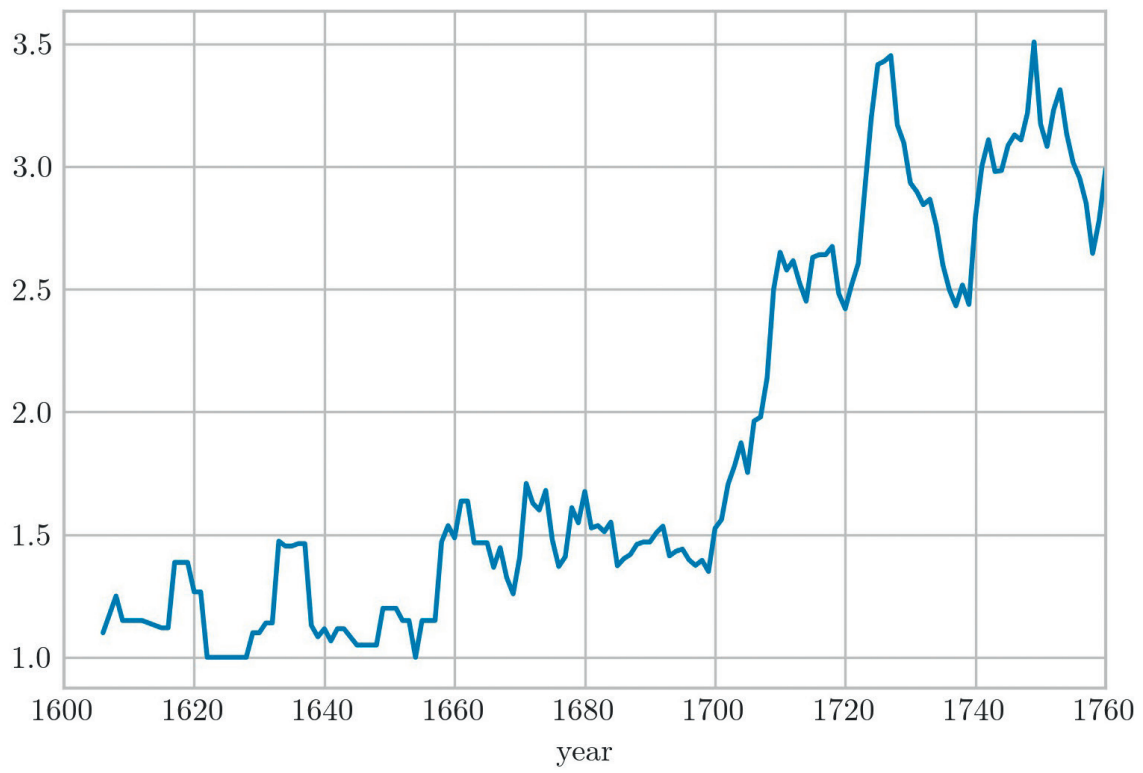

FIGURE 3 Average number of authors per publication (rolling window $=5$ ). Publications without any authors were excluded from this chart.

common, whereas three publications also occur frequently, and sometimes four or even five.

The evident increase in the average number of authors involved in each publication (Figure 3) suggests that the number of poems per booklet also increased over time. We need to take into account that single poems are less likely to survive. Besides that is it also possible that one author wrote more than one poem within a single publication, and there are indeed known examples of this happening, but even without these remarks, counting the number of unique authors provides some insight into how the number of poems within a single publication evolved over time. ${ }^{31}$ There is a great variety in the absolute number of authors: many publications have only one author during the whole period, but there are also examples of publications with between

$31 \quad$ For 662 publications we don't have the name of an author (see note 25), but for the larger part of our dataset - the remaining 3,034 publications - we know how many and which authors contributed. When we lack the names of authors, these publications were either anonymous (most probably the product of a single author) or were catalogued only in the STCN (and most probably were written by several authors). 
10 and 15 authors, and even one with $22 .{ }^{32}$ On average, as Figure 3 shows, the number of authors contributing to one publication is more or less stable during the first half of the seventeenth century. Around 1650, the average number of authors per publication increases, and from 1700 onwards, this number rises from 1.5 to 3.0 and above. Again, as with the number of publications per year, a peak occurres around 1730, when the average number of authors per publication reaches 3.5.

Our analysis also confirms the observation in the literature concerning the recurring presence of some producers (both printers and poets). Whereas the largest part of our dataset consists of agents responsible for, or contributing to only one or a few publications, smaller numbers for both the printers and the authors were remarkably active in the genre. Table 1 shows the 10 most productive printers. Together, the top 10 printers printed 572 booklets, making up $15 \%$ of the dataset. Table 2 shows the 10 most productive authors. Together, the top 10 authors wrote 865 poems, $11 \%$ of the dataset.

TABLE 1 Top 10 most productive printers

\begin{tabular}{lll}
\hline & Printer & Publications of wedding poetry 16oo-1 760 \\
\hline $\mathbf{1}$ & Johannes van Oosterwyk & $122(1700-1737)$ \\
$\mathbf{2}$ & Lescailje & $94\left(1644^{-1732)}\right.$ \\
$\mathbf{3}$ & Boeteman & $92(1681-1700)$ \\
$\mathbf{4}$ & Hendrik van de Gaete & $74(1709-1724)$ \\
$\mathbf{5}$ & Theodorus Crajenschot & $59(1744-1800)$ \\
$\mathbf{6}$ & Paulus Aertsz van Ravesteyn & $49(1610-1656)$ \\
\hline $\mathbf{7}$ & Geldorp & $23\left(1665^{-1691,1695-1722)}\right.$ \\
$\mathbf{8}$ & De Broen & $21\left(173^{2-1738,1741-1770)}\right.$ \\
$\mathbf{9}$ & Goeree & $19(1700-1726)$ \\
$\mathbf{1 0}$ & Willem Barents & $19(1720-1727)$ \\
\hline
\end{tabular}

32 This concerns a publication on the wedding of Josua van der Poorten and Hillegonda Josina van Eik in 1740 (record no. 3085). Van der Poorten was a Mennonite merchant of high distinction who wrote occasional poetry and was part of a large network of poets, as appears from mentions in many publications. Compare Smit, op. cit. (n. 14), p. 195; A.J. van der Aa, Nieuw biographisch, anthologisch en critisch woordenboek van Nederlandsche dichters, vol. 3 (Amsterdam 1846), s.v. 'Poorten (Jozua van der)'. 
TABLE 2 Top 10 most productive authors

\begin{tabular}{lll}
\hline & Author & Wedding poems 16oo-1 76o \\
\hline $\mathbf{1}$ & Claas Bruin $(1671-1732)$ & 167 \\
$\mathbf{2}$ & Anthony Jansen $(1621-1696)$ & 114 \\
$\mathbf{3}$ & Pieter Langendijk $\left(1683^{-1756)}\right.$ & 108 \\
$\mathbf{4}$ & Johannes van Oosterwyk $(1672-1737)$ & 102 \\
$\mathbf{5}$ & Jan Baptista Wellekens $\left(165^{8-1726)}\right.$ & 79 \\
$\mathbf{6}$ & Willem van der Hoeven $\left(165^{6-1727}\right)$ & 73 \\
$\mathbf{7}$ & Hendrik van de Gaete $\left(1682^{-1719)}\right.$ & 65 \\
$\mathbf{8}$ & David van Hoogstraten $\left(165^{8-1724}\right)$ & 61 \\
$\mathbf{9}$ & Hendrik Snakenburg $\left(1674^{-1750}\right)$ & 49 \\
$\mathbf{1 0}$ & Gijsbert Tysens $\left(1693^{-1732)}\right.$ & 47 \\
\hline
\end{tabular}

It is remarkable that even within the top 10 rankings of the most active printers and authors, the differences separating the first and the tenth figures are large: the most active printer from our dataset, Johannes van Oosterwyk, was responsible for 122 publications, whereas the seventh through the tenth figures in the ranking - Geldorp, De Broen, Goeree, and Willem Barents-produced only around 20 publications each $(23,21,19$ and 19 respectively). The same goes for the authors, although the differences aren't as great: the most productive author in our dataset, Claas Bruin, contributed to 167 publications, whereas the ninth and tenth authors in the ranking, Hendrik Snakenburg and Gijsbert Tysens, wrote 49 and 47 poems, respectively. We recognize many of the names of these printers and authors from our literature review: it's predictable that Van Oosterwyk, Lescailje, and Boeteman would turn out to be the most active printers in the genre, or that Bruin, Langendijk, Jansen, Van der Hoeven, and Tysens would number among the top 10 most productive authors. ${ }^{33}$

However, there are also some surprises: Hendrik van de Gaete, responsible for a fair amount both of printing jobs (74, putting him in fourth place among the printers) and of poetical contributions (65 poems, garnering him seventh place among the authors), is not a very familiar name. ${ }^{34}$ In addition, on the

33 See for example Smit, op. cit. (n. 14), Geerdink art. cit. (n. 3 and 6), Nieuweboer art. cit. (n. 4 and 9: 1986[a], 1986[b], 1993), Van der Steur, op. cit. (n. 4), Porteman \& Smits-Veldt, op. cit. (n. 10).

34 Smit, op. cit. (n. 14), pp. 41-2 mentions him in relation to the genre, but his name does not recur, for example, in Nieuweboer's publications, art. cit. (n. 4 and 9), and in Leemans \& 
basis of the existing literature, Theodorus Crajenschot's fifth place among the printers was not to be expected. ${ }^{35}$ At the same time, some names we would have anticipated are in fact missing: Nieuweboer, in her overview of occasional poetry in Haarlem, mentions Van Mater, Merkman, and Van Beaumont as the most important authors next to Langendijk, but none of these pop up in the top $10 .{ }^{36}$ Because our dataset is incomplete (see above), we have to be careful when pinpointing a 'most productive' author or printer and should not assume that people not represented in the top 10 were of no importance within the genre. Nonetheless, we can safely argue that people who are represented occupied central stage.

To gain more insight into the motives of the most productive authors and printers, we extracted a subset of the 895 publications from our dataset to which either a top-10 author or a top-10 printer contributed and created a network of all persons related to these publications, using the network visualization software Gephi. In this open-source software program, different algorithms can be performed on a dataset in order to create a network visualization from it. In our case, each node in the network represents either a printer or an author, or a wedded couple. Each edge between two nodes represents a connection between two people. ${ }^{37}$ This resulted in a network with 1,844 nodes and 9,699 edges. After running the spatialization algorithm ForceAtlas 2 on the network, we calculated the weighted degree of each edge, which is the sum of connections one node has within the network. ${ }^{38}$ This weighted degree was used as a filter, to exclude nodes with only one or two edges. ${ }^{39}$ Subsequently, we performed the 'Modularity Class' community detection algorithm, which

Johannes, op. cit. (n. 11), he is mentioned only once, and not in connection to wedding poetry.

Van der Steur, op. cit. (n. 4) mentions Crajenschot's involvement in the genre, which he situates in Catholic circles, but in the only in-depth study of Crajenschot's publishing activities, his participation in (the import of) Catholic literature in general is central and there are no references whatsoever to wedding poetry. M. Sabbe, 'Theodorus Crajenschot en de Antwerpsche boekverkoopers', in: De gulden passer, 1 (1923), pp. 54-63. Indeed, wedding poetry is not mentioned at all in the contemporary book catalogue Catalogus van Boeken, die by Theodorus Crajenschot, Boekverkooper op den hoek van de Heeregragt en Heisteeg, Amsterdam, gedrukt, aangekogt, en te bekomen zijn (Amsterdam 1757).

36 Nieuweboer, art. cit. (n. 4: 1993), p. 201. In our dataset, they are represented by 16 (Van Mater), 8 (Merkman Jr) and 2 (Van Beaumont) poems, respectively.

37 For each publication, edges were made between $(i)$ couple and printer, $(i i)$ couple and every author, (iii) printer and every author, and (iv) authors mutually. There is an edge between wedded couples mutually when they share a last name.

38 Average weighted degree: 6.892.

39 The remaining number of nodes was 1,636, corresponding with 9,374 edges. 


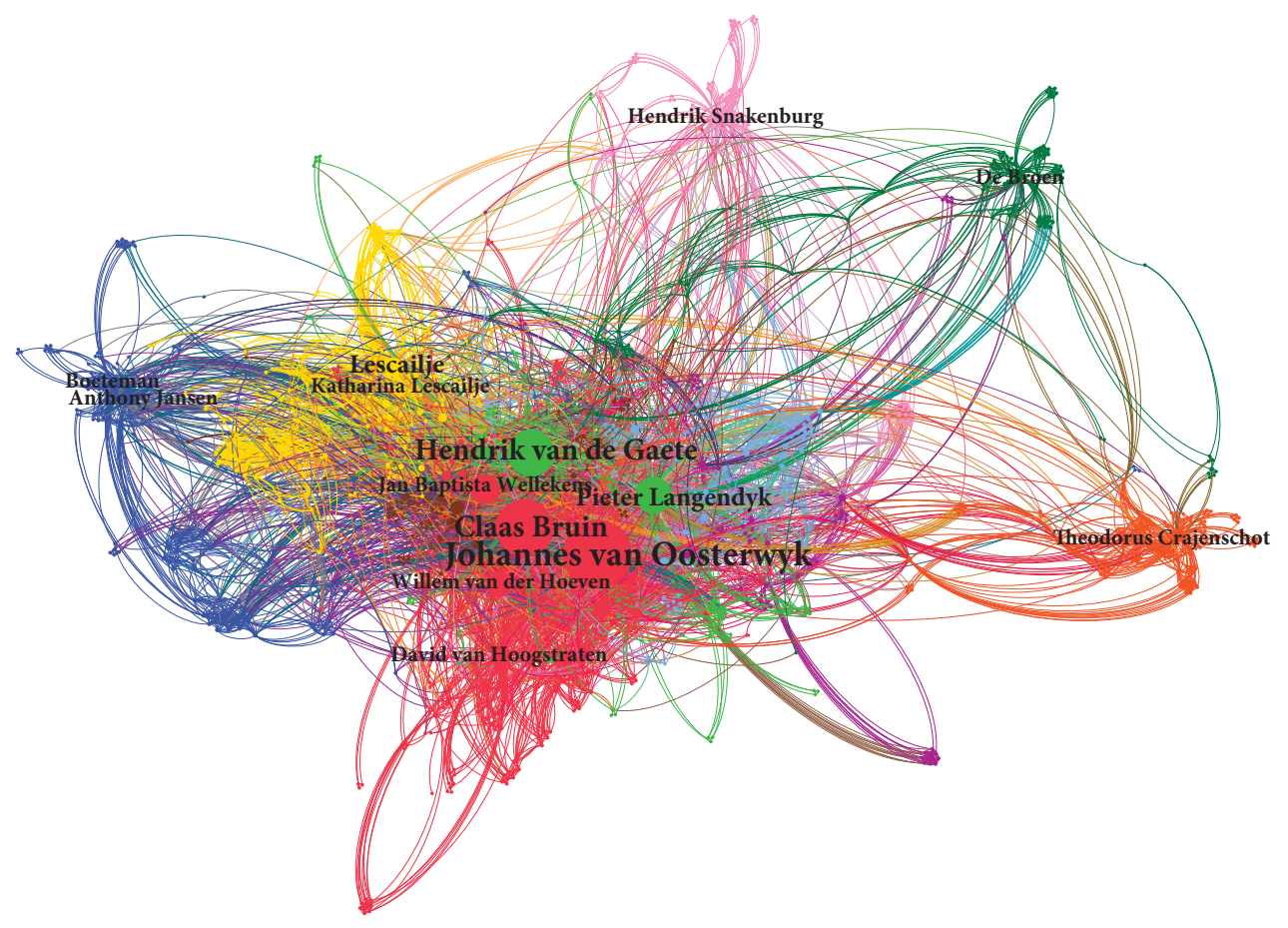

FIGURE 4 Network of top 10 printers and authors

measures how well a network decomposes into subcommunities. ${ }^{40} \mathrm{Gephi}$ detected 12 communities. In Figure 4, the 10 most dominant communities are determined by different colours, while the size of the nodes represents their weighted degree.

From this visualization, it becomes clear that some of the prominent agents within the genre were often engaged in intensive collaborations with each other. The large (red coloured) nodes refer to authors such as Claas Bruin, Jan Baptista Wellekens, Willem van der Hoeven, and Johannes van Oosterwyk. Their mutual colour suggests that they are part of the same community. Something similar can be said about the poet Anthony Jansen and the printer Boeteman: together they fulfil two dominant positions in another (blue coloured) community, indicating intensive collaboration. At the same time, however, such intensive collaboration was possible in between communities, as becomes clear from the weight of the edge between Hendrik van de Gaete and Claas Bruin, belonging to the green and red communities, respectively.

40 See https://github.com/gephi/gephi/wiki/Modularity. 
In the centre of the network there is much interaction between several communities, all based in Amsterdam-Haarlem.

\section{Social Imperatives for the Production of Wedding Poetry}

Time and again, scholars have pointed to well-known poets writing poems about the weddings of family and friends. ${ }^{41}$ This practice becomes most strikingly clear from the publications on the occasion of the Haarlem poet Elisabeth Hoofman's marriage in 1693: these include not only a publication with wedding poems from six poets from the socio-literary network of Hoofman and a separately printed poem by another poet, Pieter Rabus, but also a publication by this last poet's hand entitled 'Na-Bruilofts-Feest, of poëtisch gastmaal [...]' ('Afterparty of the wedding, or poetical banquet'). ${ }^{42}$ According to this poem, the wedded couple had invited their wedding poets to a dinner in order to thank them for their contributions to the wedding festivities.

Moreover, many poets themselves reflected-often critically—on the social obligation to write wedding poetry for friends or on behalf of friends. The disgruntled poet with whom we opened this article is one of them. ${ }^{43}$ Indeed, people asked befriended poets to help celebrate the weddings of their family members. We have some evidence from correspondence substantiating such acts of friendship. ${ }^{44}$

The genre's social status is most evident, however, from the fact that people who not regularly wrote and published poetry also composed wedding poems. In many cases the consideration whether to include a poem in a publication seems to have been influenced more by family ties than by the writer's status or the literary quality of the work. Most telling in this regard is the example of

41 Compare Van Dam, art. cit. (n. 9), p. 96; Geerdink, art. cit. (n. 3: 2010[a]), pp. 170-8; Schenkeveld-van der Dussen, op. cit. (n. 3: 1986).

42 Record no. 4, 2408 and 2409. Nieuweboer, art. cit. (n. 4: 1993), p. 191 also refers to these publications and describes the marriage as a Haarlem 'society-event'.

43 See also Nieuweboer, art. cit. (n. 4: 1986[a]), p. 58; art. cit. (n. 9: 1986[b]), pp. 16-18.

44 We know, for example, of a letter from Joannes Vollenhove in which he asks his friend Geeraerdt Brandt for information about the bride of Brandt's son, since he promised, on request, to write an epithalamium on the occasion of this son's wedding. See G.R.W. Dibbets, 'Brandtbrieven bij een trouwpartij. Iets over gender en genre aan het einde van de zeventiende eeuw', in: Nederlandse letterkunde, 2 (1997), pp. 143-55. Another letter concerning such a request is from Arnold Hoogvliet to Jakob Kortebant. Hoogvliet, in the letter, refuses to write the requested poem on the occasion of the wedding of one of Kortebant's cousins; compare Nieuweboer, art. cit. (n. 4: 1986[a]), p. 58. 
10-year-old Daniël Rutgers, the author of two poems in the 1708 publication celebrating the wedding of relatives of his parents. ${ }^{45}$

Our analysis of the dataset as a whole confirms the importance of social imperatives in the genre. Among authors and printers of wedding poetry, the larger part consists of individuals involved only in one or two publications. There are 2,591 authors in our complete dataset who contributed to one publication, and 443 authors who contributed to two. Together these 3,034 authors are responsible for the production of $39 \%$ of all non-anonymous poems in the dataset (3,034 of 7,682 poems). Since writing wedding poetry was not a common practice for these authors, we can safely assume that most of them wrote such poems only due to the immediate cause of a social event in their networks of family and friends. ${ }^{46}$ This does not necessarily mean, of course, that they were not paid for their poems or did not profit (economically) from such work in another way, via the receipt of favours in return.

A comparison of the names of participants in the genre further suggests that social imperatives were often at stake for authors. A comparison of author's last names with the last names of the bride and the groom suggests that familial ties existed between author and couple in 847 cases (see Table 3 , $423+551$ cases, minus $[8+119]) \cdot{ }^{47}$ These connections are made by 677 unique last names, which indicates that at least 677 authors, $26 \%$ of the total, wrote at least once for someone having the same last name. Of course we cannot be certain that a name connection implies a familial tie (name sharing can also be coincidental) and should note as well that people can also be related without sharing a name. Taking this into account, we believe that the large number of connections must be significant and point to an important social imperative for authors of wedding poetry.

Moreover, some publications seem to have been genuine family projects, as is most strikingly illustrated by the collection of poems for Willem Beukelaar and Elisabeth Snappers on the occasion of their $25^{\text {th }}$ wedding anniversary in 1728: all eight authors have the same last name as the groom. ${ }^{48}$ Whereas this

45 Compare Geerdink, art. cit. (n. 6; 2010[b]), p. 284.

46 It is also quite possible that among these names are those of contractors instead of poets, as described above.

47 Eight cases show overlap between the numbers for brides and grooms, because brides and grooms have the same last name. In 119 cases, there is overlap between the numbers for brides and grooms, because the bride shares her last name with one author, and the groom shares his last name with another author.

48 Isaak Beukelaar, Daniël Adrianus Beukelaar, Egidius Beukelaar, Johannes Beukelaar, Geertruid Beukelaar, Helena Beukelaar, Adriana Beukelaar, and Christina Beukelaar. Among them are a brother (Isaak) and cousins (Daniël, Egidius and Johannes). Together the four women contributed a song to the collection. 
number of related authors is exceptionally large, collections of poetry with contributions by at least two family members (based on last names) seem relatively common: this is the case for 160 publications in our complete dataset. ${ }^{49}$

As for the printers, social imperatives seem at first sight to be less significant. In the existing literature, printers play no role whatsoever with regard to the genre's social aspects..$^{50}$ The percentage of printers who were only occasionally involved in the genre is high: there are 330 printers with only one publication, and 121 printers with two. These 451 printers make up more than $70 \%$ of all printers in our dataset, printing 572 booklets. We can only speculate, however, about the imperatives that led them to occasionally print wedding poetry. The number of name connections between printers, on the one hand, and brides or grooms on the other, being far less than in the case of the authors, suggests that social imperatives might not have been as important as with authors: here we find only 40 connections made by 30 different printers, which is $4.7 \%$ of the total printers (compared to at least $26 \%$ for the authors). ${ }^{51}$

TABLE 3 Connections based on the last names of couples and authors

Connection
Publications Number of connections per publication

$\begin{array}{llllllll}1 & 2 & 3 & 4 & 5 & 6 & 7 & 8\end{array}$

\begin{tabular}{|c|c|c|c|c|c|c|c|c|}
\hline $\begin{array}{l}\text { Last name of bride } \sim \text { last name of } \\
\text { one of the authors }\end{array}$ & 423 & 328 & 81 & 11 & 3 & - & - & - \\
\hline $\begin{array}{l}\text { Last name of groom } \sim \text { last name of } \\
\text { one of the authors }\end{array}$ & $55^{1}$ & 408 & 85 & 27 & 19 & 8 & 2 & 1 \\
\hline
\end{tabular}

49 We do not give an exact number because of the possibility of overlap between the numbers for brides and grooms, but we refer here to the sum of 81 and 85 , the amount of name connections between brides and authors and grooms and authors, respectively; see Table 3 .

$5^{\circ}$ The only reference to a printer's social imperative we could find is I.H. van Eeghen, De Amsterdamse boekhandel 1680-1725, vol. 4 (Amsterdam 1967), p. 22.

51 There are 16 connections based on the last name of the bride and the printer, and 24 connections based on the last name of the groom and the printer. 
At the same time, our network analysis shows how social imperatives must have been of major importance for one of the top-10 printers, Theodorus Crajenschot. The orange coloured community around this printer (Figure 4) is far removed from other communities. He obviously served his own socioreligious network of Catholics by printing their wedding poetry, written by authors from that same network.

\section{Economic Imperatives for the Production of Wedding Poetry}

Several scholars have argued that wedding poetry was a commercial phenomenon, if only because of the immense expansion of the genre in print at the end of the seventeenth century. ${ }^{52}$ It is indeed not very likely that authors from the top-1o list given above (see Table 2) such as Anthony Jansen, who is responsible for 114 poems in our dataset, ${ }^{53}$ or printers from the top-10 list (see Table 1), such as Boeteman who printed 92 booklets with wedding poetry, engaged in these endeavours solely for the sake of friendship. It is also telling that so many different printers, who had to make a living out of such work, were involved in the genre: within our dataset alone we count 633 separate printers. ${ }^{54}$

Still, as stated in the introduction, there is not much evidence detailing the profits to be made from this type of writing, and most of the evidence we do have is circumstantial. ${ }^{55}$ An example is the very conventional poem 'Huwlyx-kroon voor Juffr. Marie de Hooge, met haren bruidegom', written by the respected poet Jan van Hoogstraten. It does not mention the groom's name and is included in the poet's collected works. ${ }^{56}$ The poem thus must have been

52 Pettegree \& Der Weduwen, op. cit. (n. 11), p. 231; Smit, op. cit. (n. 14); Nieuweboer, art. cit. (n. 4: 1988), p. 339.

53 And we know he wrote at least 28 wedding poems that are not included in our dataset, compare n. 18.

54 Nieuweboer, art. cit. (n. 4: 1986[a]), pp. 66-7, also points to the large number of individual printers.

55 See also Daamen en Meyer, op. cit. (n. 13), p. 15. Van der Steur, op. cit. (n. 4), p. 11, mentions a poem by Poot in which he would refer explicitly to the paid production of wedding poetry, but in fact Poot writes about paid commissions in more general terms, compare C.M. Geerars, Hubert Korneliszoon Poot (Castricum 1979), p. 245. It is thus not clear whether and (if so) how much Poot was paid for individual nuptial poems. About lack of evidence for the commissioned production of wedding prints see Bartelings, art. cit. (n. 29), p. 102.

56 The poem is referred to by A. de Haas, Wie de wereld bestiert, weet ik niet. Het rusteloze leven van Cornelis van der Gon, dichter en zeekapitein 1660-1731 (Amsterdam 2008), p. 74. She also concludes that the title, in combination with the conventional contents, indicates a commission. Another example is a poem by Hendrik van de Gaete included in 
a commission by the bride's family, but we lack corroborating financial records of the transaction. The same goes for the many poems that were obviously not written by a friend or relative of either the bride or the groom but were composed on behalf of such a person, who is mentioned as the commissioning party at the end of the poem. ${ }^{57}$

That such commissions could be paid for is stated clearly in a formal agreement between the early seventeenth-century poet Jan Jansz. Starter and a group of wealthy young men from Amsterdam. This group promises to pay the poet a weekly salary in return for his stay in Amsterdam and his availability to write poems on the occasion of important events in their lives, such as marriages. In the agreement, it is stated that on top of the weekly salary, Starter will receive 6 guilders for every nuptial poem he writes on commission. ${ }^{58}$ The economic possibilities for authors within the genre are confirmed more than a century later by one of its participants, Jan Goeree, in a satirical funerary ode for his colleague Willem van der Hoeven (died 1727), who is criticized for writing for money. ${ }^{59}$ Along these lines we can recall the 1733 Hollantsche Spectator episode cited at the outset: the complaining poet mentions an amount of 2 guilders as a reward for a wedding poem. ${ }^{60}$ In addition, however, there is an

his 1707 collection of poetry. In this case, the first name of the bride was left out: 'Ter bruilofte van Monsr. Antoni Schoonenburg, En de Jonge Dochter ... Knoop', in: Hendrik van de Gaete, Bruiloftszangen, Minnedichten en Mengelzangen, part I (Amsterdam 1707), pp. 30-1.

57 See Bouman, op. cit. (n. 4), p. Xv-xvi; Nieuweboer, art. cit. (n. 4: 1986[a]), p. 6o. We only know about such cases if the actual author is mentioned in the margin, compare Van der Steur, op. cit. (n. 4), p. 10; Nieuweboer, art. cit. (n. 9: 1986[b]), p. 17. In our own dataset, we found some interesting examples of this phenomenon, too, such as a poem written on behalf of the servants of the groom's business from 1721: record no. 148. It is signed with the author's name and the statement 'Dit werd met diepe eerbied opgedraagen, door de gezamentlijke Knegts der Plateel Bakkerye van de drie Klokken' (This was offered with all due respect by the joint servants of the delftware bakery of the three bells). As described in section 1, it was also possible that the commissioning individual signed the poem with his or her own name, in which case it is not evident the poem was commissioned. Anna de Haas found that in the case of Jan van Gysen, he most often did not sign commissioned poems with his own name, see A. de Haas, Jan van Gysen (1668-1722), broodschrijver in de Jordaan (Amsterdam, forthcoming).

58 A. Bredius, 'Iets over Jan Jansz. Starter', in: Oud-Holland, 3 (1885), p. 54 . The agreement is in Stadsarchief Amsterdam, not. Arch. W. Cluijt 35 o (no. 12), 25-08-1622.

59 Anna de Haas drew our attention to this poem. She elaborates on hack writing in her forthcoming book, op. cit. (n. 57).

6o In fact, he writes 'two pounds'. The pound was not a unit of Dutch currency at the time and the term was used to refer to different kinds of money, in this case probably the 'Hollandse pond', worth one guilder (2o stuivers). Compare H.E. van Gelder, De Nederlandse munten (Utrecht/Antwerpen 1966), p. 267. 
article from the Algemeene Spectator from 1742, in which 10 copies of the publication and 'een aanzienlijk boek' (a notable book) are recorded as a poet's reward for a nuptial poem. ${ }^{61}$ The truth-value of this kind of utterances is unclear, though, and Starter's agreement is a unique document. In most cases, we have no clue whether authors were paid, and if so, how much.

For printers, the fact of payment seems self-evident. Printers had to invest more than just time in these works, and printing was their profession. In another Spectator article of 1751, the amount of 6 schillings ( 36 stuivers) is mentioned as a printer's payment for one wedding poem. ${ }^{62}$ Again, we don't know whether this claim is true, nor do we possess any further details, such as the print run. We have thus no real proof of payment for printers of wedding poetry and we don't know how profitable this sort of work could be, nor which route the financial transactions took: was it the printer or the author who was asked for a poem or a booklet? We know of a signboard from a The Hague bookshop offering wedding poetry. ${ }^{63}$ Was this the rule or an exception?

It is commonly acknowledged that in relationships between printers and authors, printers were the commercial, profit-driven parties. ${ }^{64}$ In many genres, texts were published without the involvement or even the consent of the author. For the genre of nuptial poetry however, this does not go without saying. Indeed, authors wrote their poems for specific occasions, and it does not seem probable that they did not know or approve of such poems being printed in booklets commemorating such occasions. So we can wonder how they were involved. We know of at least one example in which the author was the mediator between the couple to be wed and the printer: when Cornelis van der Gon wrote a poem on the occasion of the wedding of the daughter of Tsar Peter the Great, he appears to have been asked to have 100 copies printed of it, to be delivered at the couples' courts. ${ }^{65}$ In this case, the author was the one who received the commission and mediated between commissioning agent and printer. It is generally assumed, though, that more often it was the other way around. This is indeed the route recorded in the article mentioned above from the 1742 Algemeene Spectator, in which a printer is described who

\footnotetext{
61 Quoted by Nieuweboer, art. cit. (n. 9: 1986[b]), p. 17.

62 Nieuweboer, art. cit. (n. 9: 1986[b]), p. 17.

63 It is recorded by H. Sweerts, Koddige en ernstige opschriften, vol. 3 (Amsterdam 1685), p. 71, see M. Keblusek, Boeken in de hofstad. Haagse boekcultuur in de Gouden Eeuw (Hilversum 1997), pp. 74-5. On the signboard, quite a lot of occasional genres are mentioned. It is not certain whether the board is advertising these publications as items that could be ordered (to be written and printed) or could be bought in the shop.

64 Compare Rasterhoff, op. cit. (n. 8), pp. 82-3; D. van Netten, Koopman in kennis. De uitgever Willem Jansz Blaeu (1571-1638) in de geleerde wereld van zijn tijd (Zutphen 2015).

65 De Haas, op. cit. (n. 56), pp. 195-6.
} 
was hiring poets, even asking them whether they did not have any acquaintances who were also willing to do something, since he was commissioned by a certain notable groom to supply a thick tome with poems on the occasion of his wedding. ${ }^{66}$

To complicate things further, printer and author could also be the same person: as Nieuweboer has repeatedly pointed out, some printers wrote poems for their own publications. ${ }^{67}$ Which incentives were at stake in these cases? Our own in-depth analysis of the wedding poetry of poet-printer Katharina Lescailje brought to the fore how her double role was part of a business model: Lescailje wrote many nuptial poems for couples she did not know personally. In each case, she was also the printer of the booklet containing her poem and it seems probable that (relatives of) the rich, marrying couples gave her, in return for the poem, the paid commission to print the collected wedding poetry. 68 She thus profited financially from the writing of the poems, without being paid for them directly.

With regard to the profitability of the genre for either authors or printers, our data can add some circumstantial evidence. Whereas the large numbers of people involved in the genre might be explained by both social and economic imperatives, the remarkably active group of printers and authors alike (see 'The Popularity of Wedding Poetry: Names and Numbers') hints specifically at the profitability of the production of wedding poetry. Furthermore, it appears that among the most productive printers and authors, the number of name connections with brides and grooms is relatively small: there are no name connections between top-10 authors and couples, and only four top-10 printers have, in only five cases, a name similar to that of a bride or groom (Van Oosterwyk, Van Ravesteyn, Geldorp, and De Broen). Of course, social factors were of importance for this group, too, but at first glance, the greater part of their publications of wedding poems were addressed to people they were apparently not directly related to. A further analysis of the publication lists and oeuvres of the most productive printers and authors adds to the confirmation of this hypothesis. As shown in Table 4, for several top-10 printers, a considerable part of their publications was in the genre of wedding poetry (Van

66 bezig was met Poeeten aan te neemen, hun zelfs vragende of zy geen bekenden hadden, die ook iets doen konden, vermits hy van zeker aanzienelyke Bruidegom ordre had om een dik boek met gedigten op zyn bruiloft te moeten leveren. Quoted by Nieuweboer, art. cit. (n. 9: 1986[b]), p. 17 .

67 Nieuweboer, art. cit. (n. 4: 1993), pp. 191-4; (1986[a]), p. 63; see for another example also Honig, op. cit. (n. 5), no. 85 o.

68 Geerdink, art. cit. (n. 3 and 6). 
TABLE 4 Publication activity of the top 10 most productive printers

\begin{tabular}{|c|c|c|}
\hline & Printer & $\begin{array}{l}\text { Total publications (of which wedding poetry) } \\
\text { 1600-176o (STCN) }\end{array}$ \\
\hline 1 & Johannes van Oosterwyk & $241(126)$ \\
\hline \multirow[t]{4}{*}{2} & Lescailje & Jacob Lescailje: 328 (2) \\
\hline & & Jacob erven Lescailje: $672(43)$ \\
\hline & & Dirk Rank: $196(5)$ \\
\hline & & Anthony Lescailje: 8 (o) \\
\hline 3 & Boeteman & $142(90)$ \\
\hline 4 & Hendrik van de Gaete & $146(48)$ \\
\hline 5 & Theodorus Crajenschot & $181(47)$ \\
\hline 6 & Paulus Aertsz van Ravesteyn & $302(24)$ \\
\hline \multirow[t]{2}{*}{7} & Geldorp & Jan Gerritsz Geldorp: 26 (5) \\
\hline & & Jan Gerritsz wed Geldorp: 66 (13) \\
\hline \multirow[t]{2}{*}{8} & De Broen & Gerred de I Broen: $12(7)$ \\
\hline & & Gerred de II Broen: 31 (1 1 ) \\
\hline 9 & Goeree & $29(15)$ \\
\hline 10 & Willem Barents & $45(6)$ \\
\hline
\end{tabular}

a To count the number of wedding poetry publications within all the publications of a printer, we used the same terms and wildcards as were used in creating the dataset: 'huwel" $\mathrm{k}$ ', 'br*loft"' and 'e*tver*niging*'.

TABLE 5 Publication activity of the top 10 most productive authors

\begin{tabular}{llcc}
\hline & Author & Wedding poems & Total publications (sTCN) \\
\hline $\mathbf{1}$ & Claas Bruin & 167 & 85 \\
$\mathbf{2}$ & Anthony Jansen & 114 & 173 \\
\hline $\mathbf{3}$ & Pieter Langendijk & 108 & 127 \\
$\mathbf{4}$ & Johannes van Oosterwyk & $\mathbf{1 0 2}$ & 7 \\
$\mathbf{5}$ & Jan Baptista Wellekens & 79 & 15 \\
$\mathbf{6}$ & Willem van der Hoeven & 73 & 41 \\
$\mathbf{7}$ & Hendrik van de Gaete & 65 & 9 \\
$\mathbf{8}$ & David van Hoogstraten & 61 & 81 \\
\hline $\mathbf{9}$ & Hendrik Snakenburg & 49 & 55 \\
$\mathbf{1 0}$ & Gijsbert Tysens & 47 & 71 \\
\hline
\end{tabular}


Oosterwyk, Boeteman, Van de Gaete, Crajenschot). Wedding poetry in these cases must have been among their specializations.

For the authors (Table 5), the numbers are even more convincing: the number of wedding poems in the oeuvres of five of the top-10 authors exceeds their total number of publications as catalogued in STCN, and in all other cases within the top 10, they come close. It is clear that these authors specialized in the genre, which hints at economic rather than social imperatives.

The most convincing result with regard to the profitability of the genre might be the relatively large number of publications printed by one of its authors: in $35^{1}$ publications in our dataset-almost $10 \%$ - there is overlap between the name of the printer and the name of (one of) its author(s). The number of unique printers these numbers refer to is lower: 75 for these $35^{1}$ publications, among them some very productive printers (see Table 6 and Figure 4).

TABLE 6 Printer-authors ${ }^{\mathrm{a}}$

\begin{tabular}{ll} 
Printer is author & Publications \\
\hline Johannes van Oosterwyk & 94 \\
Hendrik van de Gaete & 53 \\
Lescailje & 34 \\
Joannes van Braam & 17 \\
Geldorp & 12 \\
Arnold Willis & 12 \\
Goeree & 7 \\
Joris van der Woude & 6 \\
Petrus Dathenus & 5 \\
Hendrik Sligtenhorst & 4
\end{tabular}

a The name connection between printer and author does not necessarily mean they are one and the same. In the case of Goeree, for example, the printer was Willem II Goeree, the author his son Jan Goeree, who also made engravings for his father's publications. In this table, Goeree is, together with Geldorp, an exception, though: in all other cases, author and printer are one and the same person.

As sketched above, we knew about this practice of printers contributing to their own publications as an author, but until now we had no idea of its scale. Moreover, it turns out that some of the printers with a double role were remarkably active in the genre (see, for example, the node size of Van Oosterwyk and Van de Gaete in Figure 4), as was the case with Katharina Lescailje. This makes it very probable that her business model was common practice, an 
assumption that is reinforced by further numbers from our dataset: in the case of the two printer-poets who most often contribute to their own publications, Van Oosterwyk and Van de Gaete ( 94 and 53 times, respectively), the total number of their authored publications recorded in STCN is only seven and nine, respectively. ${ }^{69}$ For Van Oosterwyk, only one of these publications is not a wedding poem (but another occasional poem), which makes it very probable that he wrote wedding poems because of their financial remuneration. ${ }^{70}$ Although Van Oosterwyk is known as a printer with a network of literary authors, he does not seem to have possessed any ambition to make himself known as a poet. As a printer he could easily, and without any extra costs, enlarge a publication if he himself added a poem. His reward would then be bigger. Another possibility is that he added his own poem without extra charges to improve his social relationship with the commissioning party and thereby secure (future) commissions, as was probably also the case with Lescailje.

For Van de Gaete, the situation was different, although in his case, too, his oeuvre and publication list point in the direction of economic imperatives (in interaction with social imperatives). Van de Gaete participated in (partly the same) literary networks as Van Oosterwyk did, but he was also active as a (nuptial) poet before he became a printer himself, and even had published a collection of Bruiloftsdichten, minnezangen en mengeldichten ('Wedding poems, love poems, and miscellanea'), which included 11 addressed wedding poems. ${ }^{71}$ Whether he wrote due to economic imperatives cannot be decided on the basis of our data or existing scholarship about Van de Gaete, but we might speculate that his decision to start a printing house was related to his success as a wedding poet. Tellingly, he collaborated with Van Oosterwyk in later years (between 1712-1717), while both were active in the genre as both authors and printers.

The case of Van de Gaete suggests that the best position within the genre, from an economic perspective, was that of the printer, otherwise there would have been no need for him to become one. This observation reinforces the

69 Van Oosterwyk wrote a total of 102 wedding poems in our dataset: eight times for a publication for which we don't know the printer. Van de Gaete wrote a total of 65 wedding poems. He also wrote eight poems in anonymously printed publications, and he contributed four times to a publication with wedding poetry printed by someone else (twice Lescailje, once Jacob van Royen, and once Boeteman).

70 Possibly, Paulus in Areopágo, a non-occasional publication, is from the hand of Van Oosterwyk. This is suggested by STCN, since it is printed by Van Oosterwyk and signed 'J. Oe'.

71 Biographical information about Van de Gaete can be found most extensively in Smit, op. cit. (n. 14), pp. 41-2. His collection of poetry: Hendrik van de Gaete, Bruiloftsdichten, minnezangen en mengeldichten (Amsterdam 1707). 
general assumption put forward in the existing scholarship, that most often the printer received the commission and then asked authors to cooperate. Indeed, in the case of Van de Gaete, his intense collaboration with Pieter Langendijk, also visible in the network visualization, points to such a route. ${ }^{72}$ When analysing the network's sub communities in more detail, it becomes possible to add to this kind of evidence. There is, for example, a cluster of related couples with either a bride or a groom from the Van Halmaele family that had its booklets with wedding poetry printed by Lescailje. Whereas the printer is always the same (Lescailje), the authors contributing to the booklets differ, although the individual authors all contributed to more than one publication of this specific printer. This suggests the printer was the recipient of the commission, asking around for contributors within his network of authors.

The case of this sub community also shows pre-eminently how economic and social imperatives interacted within the genre-not only because the familial ties between the couples most probably led to the paid commission being given to one and the same printer, but also, and to an even greater extent, because members of the Van Halmaele family are also among the authors. These authors must have written their poems primarily due to social imperatives, while the printer and possibly other contributing authors did so primarily due to economic imperatives.

\section{Concluding Remarks}

The interaction between social and economic imperatives is characteristic of the genre of wedding poetry. Our analysis confirms the importance of both economic and social contexts within the genre. There is a clear distinction between a large group of printers and authors participating in the genre occasionally, and a smaller group of very productive participants, but it is impossible to completely distinguish between social and economic imperatives among these people and they are often obviously related. Whereas this is something you could say more generally about early modern literature, social and economic imperatives are tied up even more tightly within the genre of wedding poetry, which always marks significant social events (just as, for example, elegies or birthday poems do) but which is the only occasional genre that became a genuine business in the first half of the eighteenth century as part of the commercial, profit-driven book market.

72 This is also what Smit supposes: Smit, op. cit. (n. 14), p. 42. 
To get a more complete view of the genre's scale and scope and of the networks and forms of agency within it, as well as explain the remarkable peak around the 1730s, future research should take various directions. In the first place, the representativeness of our dataset could be analysed in more detail by comparing analyses of the data from the used catalogues separately, and by relating our data to marriage records in general. Second, our dataset should be enlarged with data that are not (digitally) available yet or that could not be included in our dataset for other reasons, such as geographical data, data concerning the appearance of the publications, data concerning the printing industry (for example the price of paper), and names of anonymous printers to be retrieved with the help of Arkyves. In the network analysis, biographical details about the participants could be incorporated to gain more insight into external factors responsible for relationships and (thus) the interaction between social and economic imperatives.

It is as least as important, however, to use our data-driven analysis as a point of departure for in-depth case studies. The network we visualized is a fruitful gateway to find those communities, persons or publications whose cases might enlighten us about the specifics of the genre, if analysed from multiple perspectives at the same time (including all relevant biographical, genealogical, book-historical, literary and contextual details concerning the publications and its agents). Fourth, both in case studies and in elaborations on our largescale quantitative analysis, an internationally comparative perspective could be rewarding. If anything, this article has shown the combination of qualitative and quantitative research to be promising and pivotal to future research on the intersections between social and economic imperatives in early modern cultural industries. 